\title{
SOBRE A RELAÇÃO ENTRE ESCOLA/TEORIA E MUNDO/PRÁTICA NA PERSPECTIVA COSMOPOLÍTICA EM KANT
}

On the relationship between school/theory and world/ practice in Kant's cosmopolitics perspective

\author{
Leandro Shigueo Araújo* \\ Victor Fernandes Travaglia**
}

\begin{abstract}
Resumo: O trabalho teórico em filosofia pode se associar com a prática do filósofo? Se há essa possibilidade, como deve o filósofo fazêlo? Em termos mais gerais, o que vale na teoria filosófica também vale para a prática? Neste trabalho pretendemos especificar este problema e dar respostas a essas questões com base nos escritos de Immanuel Kant. Aspiramos esclarecer como Kant concebe a função prática à teoria desenvolvida no campo acadêmico (escola), fundamentando sua perspectiva no foco cosmopolita que todo cidadão racional deve exercer. Além disso, pretendemos mostrar como o próprio Kant nos fornece um exemplo dessa associação entre teoria e prática nos campos moral, político e cosmopolítico. Desse modo, dividiremos o trabalho da seguinte maneira: na primeira parte, explicaremos a noção que Kant tem de filosofia e da função dupla que o filósofo possui, além de associarmos e justificarmos os pares escola e mundo com teoria e prática; nas partes seguintes, mostraremos como o filósofo alemão mostra em casos concretos essa associação no campo moral, político e cosmopolítico; por fim, concluiremos com respostas às questões supracitadas.
\end{abstract}

Palavras-chave: Moral. Direito Político. Immanuel Kant. Teoria e Prática. Escola e Mundo.

\begin{abstract}
The theorical work in philosophy may be associated with the practice of the philosopher? In general terms, what applies in the philosophical theory also applies in the practice? In this work we pretend to specify this problem and give answers to these questions based on the writings of Immanuel Kant. We aim to clarify how Kant conceives the practical function to theory developed in the academic field (school), basing your perspective cosmopolitan in cosmopolitan focus that every rational citizen should exercise. In addition, we pretend to show how Kant gives us an example of this association between theory and practice in the moral fields, political and cosmopolitical. In this way, we share the work as follows: the first part, we explain the notion that Kant's have of philosophy and the dual function that the philosopher has, beyond associate and justify the pairs school and world with theory and practice, in the following parts, we show how the german philosopher shows in concrete cases this association in the moral fields, political and cosmopolitical, and finally conclude with answers to the questions above.
\end{abstract}

Keywords: Moral. Political Right. Immanuel Kant. Theory and Practice. School and World.

* Mestrando em Ética e Política no Programa de Pós-Graduação em Filosofia da Universidade Federal de Uberlândia (UFU). Contato: leandroshigueo@gmail.com

** Mestrando em Ética e Política no Programa de Pós-Graduação em Filosofia da Universidade Federal de Uberlândia (UFU). Contato: suportevic@gmail.com

\begin{tabular}{|c|c|l|l|l|l|}
\hline intuitio & $\begin{array}{c}\text { ISSN } \\
1983-4012\end{array}$ & Porto Alegre & Vol.7 $-\mathrm{N}^{\mathrm{o}} .1$ & $\begin{array}{c}\text { Junho } \\
2014\end{array}$ & p.112-124 \\
\hline
\end{tabular}




\section{Introdução}

O objetivo inicial deste trabalho é mostrar como I. Kant desprende da concepção de filósofo a ideia de que este deve ser um mero acadêmico, preocupado com sistemas conceituais que não se relacionam com a vida prática das pessoas. Em outras palavras, pretendemos mostrar como Kant empreende uma função prática (moral) para todo filósofo em uma perspectiva civil. Nesse sentido, nosso primeiro objetivo é compreender aspectos de formação do filósofo, ou seja, pedagógicos.

Para cumprir este objetivo, partimos da associação entre os pares filosofia na escola /no mundo e teoria/prática. A associação é feita a partir de textos diversos de Kant que envolvem tanto o "Manual dos Cursos de Lógica Geral" quanto os escritos de 1793 encontrados em "A Paz Perpétua e outros Opúsculos" "2. Desse modo, o ponto de partida do nosso trabalho versará sobre a concepção que Kant tem da filosofia, enquanto teoria da escola e legisladora no mundo.

Utilizaremos como fundamento dessa associação o papel cosmopolita que o filósofo, como cidadão do mundo, deve ter para que teoria e prática - filosofia na escola e no mundo - não sejam dissociadas. Ainda nesse ponto, tentaremos mostrar como se justifica essa associação por meio de três argumentos desenvolvidos a partir da leitura que faremos de diferentes escritos de Kant.

Por fim, pretende-se mostrar de que modo teoria e prática se associam sob três perspectivas: (1) na moral, do homem privado, mas prático; (2) no campo do direito, ou do homem político; e por fim, (3) no campo cosmopolita, ou do homem como cidadão do mundo.

\section{A Associação e sua justificação}

Um discurso sobre a formação e a função de um determinado profissional de qualquer que seja a área deve ter uma boa concepção sobre a própria profissão. Por exemplo, para saber a função e como deve ser a formação de um médico, deve-se previamente saber o que é a disciplina medicina. Talvez isso não faça tanto sentido quanto na filosofia. E, é isso o que discutiremos neste tópico.

Se questionarmos qual é o sentido do termo "filosofia", seu caráter e sua utilidade, podemos encontrar a resposta nas proposições de I. Kant. Para ele, a filosofia tem duas partes complementares: uma que pode ser apreendida e diz respeito a sua função na escola e outra que não pode proceder desse modo e diz respeito a sua função no mundo.

Sobre a primeira parte da concepção de filosofia temos que, por um lado, ela é um conhecimento do tipo racional, em oposição ao histórico. Ou seja, a filosofia não opera com meros dados (histórico ou empírico), mas por princípios universais, que são abstraídos de regras gerais. A

\footnotetext{
${ }^{1}$ KANT, Immanuel. Manual dos cursos de lógica geral. Tradução e apresentação de Fausto Castilho. Edição bilíngüe. Campinas: IFCH-UNICAMP; Uberlândia: EDUFU, 1998.

${ }^{2}$ KANT, Immanuel. A Paz Perpétua e outros Opúsculos. Tradução de Artur Morão. Lisboa: Edições 70, 1995.
}

\begin{tabular}{|l|c|l|l|l|l|}
\hline intuitio & $\begin{array}{c}\text { ISSN } \\
1983-4012\end{array}$ & Porto Alegre & Vol.7 - No.1 & $\begin{array}{c}\text { Junho } \\
2014\end{array}$ & p.112-124 \\
\hline
\end{tabular}


fonte do conhecimento geral incluindo, portanto, da filosofia, pode ser objetiva, quando se refere aos objetos, ou subjetiva, quando se refere ao modo como esse objeto é apreendido.

Em outro texto publicado em 1793, Kant definiu "teoria" como um "conjunto de regras práticas numa certa universalidade, e aí se abstrai de um grande número de condições, as quais, no entanto, têm necessariamente influência sobre sua aplicação"3. Essa concepção não apenas se assemelha com o conhecimento filosófico supracitado, como também parece complementá-lo. Desse modo, a associação entre filosofia na escola e teoria parece lúcida. O papel do filósofo na escola parece ser o seguinte: usar a sua habilidade de técnico da razão para construir regras a partir dos dados e abstrair princípios gerais ou universais para quaisquer objetivos. Vale mencionar aqui a passagem de Aramayo sobre um dos sentidos que Kant atribui ao "esclarecimento", o qual se relaciona pertinentemente com o significado de "filosofar": "Servirse de la própria razón no significa outra cosa que perguntarse a si mismo si uno encuentra factible convertir en principio universal del uso de su razón el fundamento por el cual admite algo o tambíen la regla resultante de aquello que asume"4.

Mas o que dizer do aprendizado da história da filosofia? Para Kant ${ }^{5}$, ela também é uma parte fundamental para o ato de filosofar, todavia a forma com que o filósofo a apreende dá-se de maneira distinta. Nesse sentido, considerada como história, a filosofia é um mero arcabouço de dados e funciona mais como um conhecimento do tipo empírico ou histórico.

No que diz respeito à segunda parte da concepção de filosofia - a filosofia no mundo - $\operatorname{Kant}^{6}$ afirma que ela é o próprio filosofar, isto é, o uso autônomo da razão visando sempre legislar ou construir máximas (regras) para o fim último da razão humana. Este ponto é associável com o que Kant $^{7}$ chama de "prática" em outro momento: "[...] efetuação de um fim conseguida como adesão a certos princípios de conduta representados na sua generalidade"8. Assim, para Kant, teoria e prática são ligadas do mesmo modo que a filosofia no mundo relaciona-se com a filosofia na escola. São partes distintas, mas indissociáveis.

Para justificar essas associações, podemos desenvolver três argumentos retirados do próprio Kant ${ }^{9}$. Primeiro, uma teoria incompatível com a prática carece de sentido. Se analisarmos essa sentença do ponto de vista moral, um conceito como "dever", por exemplo, seria vazio de sentido se ele não intentasse certo efeito ou não fosse possível na experiência ${ }^{10}$. Isto é, se construirmos uma teoria sobre os princípios que devem reger a conduta humana e essa teoria não pode ser praticada, não há sentido em tal teoria.

\footnotetext{
${ }^{3}$ KANT, Immanuel. A Paz Perpétua e outros Opúsculos, p.57.

${ }^{4}$ ARAMAYO, 2004, p.10. Servir-se da própria razão não significa nada mais que perguntar a si mesmo se é possível converter em princípio universal do uso da sua razão, o fundamento pelo qual admite algo ou também a regra resultante daquilo que assume (tradução nossa).

${ }^{5}$ Cf. KANT, Immanuel. Manual dos cursos de lógica geral.

${ }^{6} \mathrm{Cf}$. KANT, Immanuel. Manual dos cursos de lógica geral.

${ }^{7}$ Cf. KANT, Immanuel. A Paz Perpétua e outros Opúsculos.

${ }^{8}$ KANT, Immanuel. A Paz Perpétua e outros Opúsculos, p.57.

${ }^{9}$ Cf. KANT, Immanuel. A Paz Perpétua e outros Opúsculos.

${ }^{10}$ KANT, Immanuel. A Paz Perpétua e outros Opúsculos, p.59.
}

\begin{tabular}{|l|c|l|l|l|l|}
\hline intuitio & $\begin{array}{c}\text { ISSN } \\
1983-4012\end{array}$ & Porto Alegre & Vol.7- $\mathrm{N}^{\mathrm{o}} .1$ & $\begin{array}{c}\text { Junho } \\
2014\end{array}$ & p.112-124 \\
\hline
\end{tabular}


Segundo, uma teoria pode ser incompleta por si só e a prática pode ajudar a construir regras que completem a teoria. Como diz Kant,

A teoria pode ser incompleta e o complemento da mesma pode talvez ter lugar só através de tentativas e de experiências ainda por fazer, a partir das quais o médico ao sair da escola, o agricultor ou o fiscal, pode e deve abstrair para si novas regras e completar assim a teoria. ${ }^{11}$

Terceiro, uma teoria incompatível com a prática inviabiliza um sistema (totalidade). Por exemplo, uma teoria moral que não pode ser aplicada a todas as pessoas, sem o intuito de se tornar universal, inviabiliza o alcance global dessa teoria sobre a prática.

Após os esclarecimentos e as justificativas sobre a associação entre escola/teoria e mundo/prática, podemos passar para as aplicações que Kant faz dessa associação na moral, no direito e na perspectiva cosmopolita.

\section{Sobre teoria e prática na moral}

Kant define a moral como "uma ciência que nos ensina como devemos não nos tornar felizes, mas dignos da felicidade" ${ }^{2}$. Para Kant, essa moral representa a condição suprema do homem. O mérito de ser feliz é uma qualidade pessoal fundada no próprio querer do sujeito, em conformidade com uma razão legisladora universal - tanto da natureza quanto do livre querer. Desse ponto de vista, o mérito de ser feliz harmoniza-se com todos os objetivos pessoais do indivíduo.

Essa noção de dever apresentada por Kant é o bem supremo do homem. O dever não pode vir do campo da sensibilidade, pois exige uma obediência incondicionada e basta a si mesmo. O dever não precisa de nenhuma influência ou inclinação e, o mais importante, representa o cânone da razão, na qual o valor da prática fundamenta-se inteiramente em sua conformidade com a teoria que lhe está subjacente.

O conceito de dever é mais claro no uso prático. Ele impera categoricamente e distingue-se da máxima que nos prescreve seguir o fim que, em geral, é chamado de felicidade e é proposto pela própria natureza como um motivo para certo modo de agir. Segundo Kant,

[...] que o homem deva cumprir o seu dever de um modo totalmente desinteressado e deva separar do conceito do dever a sua ânsia de felicidade para ter aquele em toda a sua pureza, disso ele é consciente com a máxima clareza [...]. ${ }^{13}$

A felicidade não será tratada como causa da moralidade, mas como uma consequência:

A pessoa deve pautar sua ação tendo como única motivação a lei moral e, só então, pode esperar que a felicidade possa ser-lhe atribuída. Ou seja, a vontade boa é posta como condição de felicidade. ${ }^{14}$

\footnotetext{
${ }^{11}$ KANT, Immanuel. A Paz Perpétua e outros Opúsculos, p.58.

${ }^{12}$ KANT, Immanuel. A Paz Perpétua e outros Opúsculos, p.61.

${ }^{13}$ KANT, Immanuel. A Paz Perpétua e outros Opúsculos, p.68.
}

\begin{tabular}{|c|c|l|l|l|l|}
\hline intuitio & $\begin{array}{c}\text { ISSN } \\
1983-4012\end{array}$ & Porto Alegre & Vol.7- No.1 & $\begin{array}{c}\text { Junho } \\
2014\end{array}$ & p.112-124 \\
\hline
\end{tabular}


Assim, é da felicidade, em seu sentido mais geral, que surgem os motivos de todo o esforço para a obediência à lei moral. Entretanto, o homem verdadeiramente virtuoso jamais se esforça por ser feliz, pois sua virtude consiste em submeter-se ao dever.

A vontade, segundo Kant, é uma lei incondicional da razão e uma lei moral do dever. Devemos sempre obedecer à lei moral e fazer de tudo que está ao nosso alcance para que exista uma relação entre essas leis. A noção de vontade está subordinada à de dever, ou seja, caso seja necessário restringirei a minha vontade em prol de uma legislação universal, que é mais importante do que o próprio princípio de felicidade. Além disso, o homem é consciente a ponto de preferir a lei moral do dever, pois ela

[...] não é apenas um estado melhor, mas o único que em se é bom, [...] diferente da felicidade, onde uma ação pode contribuir mais e outra menos para minha felicidade, por conseguinte pode ser melhor ou pior que outra. ${ }^{15}$

Para Kant, a relação entre dever e felicidade fica clara na seguinte afirmação: "Em primeiro lugar, devo estar certo que não ajo contra meu dever; só em seguida me é permitido olhar à volta em busca da felicidade, contanto que eu a possa conciliar com o meu estado moralmente (e não fisicamente) bom. ${ }^{16}$ Assim, a felicidade constitui o fundamento de toda a necessidade objetiva de agir, ou seja, de toda obrigação.

Nenhuma idéia eleva mais o ânimo humano e o estimula até o entusiasmo do que precisamente a de uma pura disposição moral que honra o dever acima de tudo, luta com os inumeráveis males da vida e até com as suas tentações sedutoras e, no entanto (como com razão se admite que o homem é disso capaz), sobre elas triunfa. Que o homem seja consciente de que pode porque deve. ${ }^{17}$

A verdade da moral é compreendida como ciência somente se é deduzida da forma pura da razão e não do conteúdo material da experiência. Isso por que a razão tem em si mesma a força para desenvolver uma ética que seja universalmente válida e, por conseguinte, não seja meramente subjetiva. Devemos fundamentar a lei moral na própria razão prática pura e tão somente nela. Dessa forma, exigir que a razão pura seja prática é exigir que ela determine sua vontade como independente de toda e qualquer inclinação. Assim, “[...] na moral, tudo o que é correto na teoria deve também valer para a prática." 18

\section{Sobre teoria e prática no direito}

${ }^{14}$ DUTRA apud NODARI, Paulo César. A teoria dos dois mundos e o conceito de liberdade em Kant. Caxias do Sul: Educs, 2009, p.156.

${ }^{15}$ KANT, Immanuel. A Paz Perpétua e outros Opúsculos, p.66.

${ }^{16}$ KANT, Immanuel. A Paz Perpétua e outros Opúsculos, p.67.

${ }^{17}$ KANT, Immanuel. A Paz Perpétua e outros Opúsculos, p.72.

${ }^{18}$ KANT, Immanuel. A Paz Perpétua e outros Opúsculos, p.73.

\begin{tabular}{|c|c|c|c|c|c|}
\hline intuitio & $\begin{array}{c}\text { ISSN } \\
1983-4012\end{array}$ & Porto Alegre & Vol.7- $\mathrm{N}^{\mathrm{o}} .1$ & $\begin{array}{c}\text { Junho } \\
2014\end{array}$ & p.112-124 \\
\hline
\end{tabular}


Na seção intitulada "Da relação da Teoria à Prática no Direito Político"19. Kant mostrará de que modo os princípios puros e racionais do direito humano externo em geral (teoria) instruem o Estado na instituição de leis para uma comunidade estável (prática). Em termos mais simples, como teoria e prática convergem em uma totalidade no campo do direito político. O pressuposto do qual Kant parece partir é o contratualismo, no qual os homens se unem em sociedade para determinados fins.

Para o filósofo alemão, a constituição civil é um tipo de contrato social que une as pessoas, mas diverge de todos os demais contratos já em seu surgimento. Seria assim porque todos os outros contratos sociais, salvo a constituição civil, visam a um fim determinado. Para Kant, não haveria motivos ou interesses externos para as pessoas se unirem, como segurança ou felicidade. Mais que isso, o enredamento em influência recíproca das pessoas, diz Kant, "é um dever incondicionado e primordial" ${ }^{20}$. Segundo Ferraz ${ }^{21}$, o estado de natureza é conflituoso, por isso, seriam necessárias leis coercitivas que garantissem o convívio social. ${ }^{22}$

Esse dever gera o direito sob leis públicas de coação, isto é, as pessoas se unem livremente, mas têm sua liberdade limitada pela liberdade de outrem. Caso a liberdade de outrem seja afetada, este tem o direito de coagir o desafeto. Por exemplo, imagine que um desconhecido cometa um crime contra mim, ferindo a minha liberdade (busca pela felicidade). Eu tenho o direito de requisitar a polícia, para que tal pessoa pague pelo crime. Isso é estar submetido às leis públicas de coação ${ }^{23}$. Segue-se então que, apesar das pessoas no estado civil serem livres, sua liberdade é restringida pelo arbítrio de outrem. Isso parece ser uma garantia de que as pessoas não entrem em conflito, mas não Kant não nega que ele continue a ocorrer. Até mesmo por que Kant não parecia estar preocupado em restringir a liberdade oferecida no estado de natureza. Pelo contrário, ele quer mantê-la, mas sem que esta seja selvagem e sem lei. Kant gostaria que ela se tornasse juridicamente possível, enquanto autonomia para legislar sobre si mesmo e procurar sua própria felicidade sem que, para isso, tenha que atingir a liberdade dos outros.

Para Kant, este estado civil considerado apenas enquanto uma situação jurídica, funda-se nos seguintes princípios: liberdade, igualdade e independência ${ }^{24}$. Para $\mathrm{Ferraz}^{25}$, Kant assere que a constituição civil de cada Estado deve ser republicana. Diz o comentador:

${ }^{19}$ KANT, Immanuel. A Paz Perpétua e outros Opúsculos, p.73.

${ }^{20}$ KANT, Immanuel. A Paz Perpétua e outros Opúsculos, p.74.

${ }^{21}$ Cf. FERRAZ, C. A. "Quando Ética e Política se encontram: Kant, o projeto de 'À Paz Perpétua' e as bases para um 'Direito dos Povos”'. In: Dissertatio: Revista de Filosofia. v. 34, pp. 209-229, 2011. Disponível em: <http://www.ufpel.edu.br/isp/dissertatio/revistas/34/09.pdf>. Acesso em: 10/02/2013.

${ }^{22}$ Cf. FERRAZ, C. A. "Quando Ética e Política se encontram", p.211.

${ }^{23}$ Para usar um caso concreto, veja o que diz o Art. 151 do Código Civil Brasileiro: "A coação, para viciar a declaração da vontade, há de ser tal que incuta ao paciente fundado temor de dano iminente e considerável à sua pessoa, à sua família, ou aos seus bens". Disponível em: $<$ http://www.planalto.gov.br/ccivil_03/leis/2002/L10406.htm>.

${ }^{24}$ Cf. KANT, Immanuel. A Paz Perpétua e outros Opúsculos, p.75.

${ }^{25}$ Cf. FERRAZ, C. A. "Quando Ética e Política se encontram".

\begin{tabular}{|c|c|l|l|l|l|}
\hline intuitio & $\begin{array}{c}\text { ISSN } \\
1983-4012\end{array}$ & Porto Alegre & Vol.7- $\mathrm{N}^{\mathrm{o}} .1$ & $\begin{array}{l}\text { Junho } \\
2014\end{array}$ & p.112-124 \\
\hline
\end{tabular}


Isso porque Kant entende por "república" algo similar àquilo que entendemos, hoje, por "democracia representativa liberal". Temos aqui, como primeiros direitos do cidadão, a liberdade, a igualdade (não no sentido econômico) e a independência (Selbständigkeit), isto é, o poder de participar do governo mediante o voto. Tal modelo de governo, o republicano, seria o único capaz de garantir a saída daquela situação. ${ }^{26}$

A situação à qual Ferraz se refere é o estado de natureza conflituoso.

O princípio da liberdade é explicitado por Kant da seguinte maneira: “[...] a cada um é permitido buscar a felicidade pela via que lhe parecer boa, contanto que não cause dano à liberdade dos outros [...] segundo uma lei universal possível" ${ }^{\text {"27 }}$. Como exemplo, Kant mostra que o pior tipo de despotismo é aquele de um governo paternal que trata seus súditos como crianças que não sabem o que as tornam felizes. O ideal, para ele, é que o governo seja patriótico, em que todos os cidadãos, inclusive o chefe de Estado, considerem-se responsáveis por preservar os seus direitos, por meio de leis que derivem da vontade comum, longe de caprichos e de vontades particulares.

Em relação à igualdade, a fórmula kantiana é a seguinte: "Cada membro da comunidade possui um direito de coação sobre todos os outros" ${ }^{28}$. Essa igualdade se difere em qualidade ou grau da sua propriedade e direito. Nos primeiros aspectos pode haver diferença, por exemplo, entre um empresário que manda em um empregado por causa da relação especial que mantém com este. Mas enquanto direito, a igualdade não pode ser distinguida entre os cidadãos. Para exemplificar, pense no empresário, dono de loja de calçados que pode contratar e mandar em seus empregados, todavia, não pode torná-los seus escravos.

Por fim, sobre o princípio da independência, Kant afirma que o cidadão comum co-legisla as leis de seu Estado. Mas apenas como protegido, que tem a obrigação de observar tais leis - de fato estabelecidas pelo legislador - pois participa da proteção que elas lhes garantem. O que Kant parece dizer é que o cidadão comum escolhe por meio do voto quem o representará na formação das leis de sua comunidade. Mas parece também haver uma pequena diferença com o que ocorre atualmente. Hoje, escolhemos representantes que sanam ou prometem sanar as vontades de cada um ou de pequenos grupos. Porém, Kant alega que nesse processo de formação de leis e, portanto, de direitos, a vontade de todo o povo é imprescindível para que tais leis sejam justas. Se criadas pela vontade comum, temos o que Kant chama de contrato originário. Nenhuma vontade individual pode sobreporse à vontade comum. Portanto, a personalidade moral do cidadão torna-se personalidade civil.

Na sequência da seção, Kant irá explicar porque após a escolha dos governantes, não há possibilidade de revolta por parte da população. Em linhas gerais, ele explicitará que, depois de estabelecidos todos os princípios que guiarão a formação das leis e dos direitos, não há possibilidade

${ }^{26}$ FERRAZ, C. A. “Quando Ética e Política se encontram”, p.211-212.

${ }^{27}$ KANT, Immanuel. A Paz Perpétua e outros Opúsculos, p.75.

${ }^{28}$ KANT, Immanuel. A Paz Perpétua e outros Opúsculos, p.76. Para Kant, o único que constitui exceção a essa fórmula é o próprio Chefe de Estado. Ele não pode sofrer nenhum tipo de coação, mas pode solicitá-la e aplicála.

\begin{tabular}{|l|c|l|l|l|l|}
\hline intuitio & $\begin{array}{c}\text { ISSN } \\
1983-4012\end{array}$ & Porto Alegre & Vol.7 $-\mathrm{N}^{\mathrm{o}} .1$ & $\begin{array}{c}\text { Junho } \\
2014\end{array}$ & p.112-124 \\
\hline
\end{tabular}


de mudança. Se essa possibilidade existisse, teoria e prática seriam inconciliáveis ou haveria outros princípios regentes.

Primeiramente, Kant fala sobre a importância da vontade coletiva de um povo (corolário originário) implicada na função do legislador. Para ele, a justificativa disso não precisa ser encontrada na história da humanidade, porque seria uma "simples ideia da razão, a qual teria sua realidade indubitável"29. Vale lembrar, como bem o faz o filósofo alemão, que o voto não espelha a vontade de todos, mas a da maioria. Seria impossível acatar aquela vontade (qual?). Apesar disso, é por vontade de todos que a vontade da maioria reina. A única possibilidade justa é que a minoria acate essa vontade para o bem comum.

Posto isso, Kant alega que se um legislador estabelecer uma lei que diminua a felicidade da população, essa população não pode resistir. Primeiramente, porque a felicidade na filosofia kantiana não constitui um princípio regulador; além disso, quem deve regular a sua felicidade é o próprio cidadão. O papel do legislador é garantir essa liberdade como um direito a todos, ou seja, todos podem buscar a sua felicidade, desde que não causem dano legal a nenhuma outra pessoa.

Em segundo lugar, Kant alega que a felicidade não constitui um princípio universalmente, nem dela pode um ser derivado:

Se o poder supremo estabelece leis que visam diretamente a felicidade (o bem estar / dos cidadãos, a população, etc.), isso acontece não como fio de estabelecer uma constituição civil, mas como meio de garantir o estado jurídico sobretudo contra os inimigos externos do povo. ${ }^{30}$

Se uma lei é conforme o direito, ela não pode ser constrangida. Mas se ela é conforme a felicidade e irrepreensível em relação ao direito caber-lhe-ia o constrangimento. Entretanto, o constrangimento não pode acontecer por meio da violência, tendo em vista que isso violaria ou aniquilaria toda e qualquer constituição civil. Por isso, Kant considera o descontentamento violento dos súditos como o crime mais grave e punível ${ }^{31}$.

Em terceiro lugar, em uma constituição civil já existente, o povo já não tem por direito a decisão de determinar como é que ela deve ser administrada ${ }^{32}$. Isso ocorreria, por que Kant entende que não há instituição pública aceitável que julgue quem está certo: o povo ou o legislador ${ }^{33}$. Contrariando Achenwall, o qual alega que o povo poderia resistir a um ato de ameaça à comunidade por parte do Estado, Kant reafirma que isso se trata de uma máxima ilegitimidade. Isso porque essa resistência tornaria insegura toda a constituição jurídica e introduziria um estado pautado ausência de leis, em que todo o direito cessa ou, pelo menos, deixa de ter efeito. ${ }^{34}$

\footnotetext{
${ }^{29}$ KANT, Immanuel. A Paz Perpétua e outros Opúsculos, p.83.

${ }^{30}$ KANT, Immanuel. A Paz Perpétua e outros Opúsculos, p.84.

${ }^{31}$ Cf. KANT, Immanuel. A Paz Perpétua e outros Opúsculos, p.85.

${ }^{32}$ Cf. KANT, Immanuel. A Paz Perpétua e outros Opúsculos, p.86.

${ }^{33}$ Atualmente, sabemos que isso é possível em uma república que possui poderes independentes, como no caso do Brasil, em que o legislativo e o executivo poderiam ser julgados pelo judiciário.

${ }^{34}$ KANT, Immanuel. A Paz Perpétua e outros Opúsculos, p. 88.
}

\begin{tabular}{|c|c|l|l|l|l|}
\hline intuitio & $\begin{array}{c}\text { ISSN } \\
1983-4012\end{array}$ & Porto Alegre & Vol.7- No.1 & $\begin{array}{c}\text { Junho } \\
2014\end{array}$ & p.112-124 \\
\hline
\end{tabular}


Para Kant, somente haveria motivos para revoltas quando o Estado, de maneira déspota, ousasse estabelecer leis que se fundassem na felicidade. Se toda lei inquirida fosse incumbida ao direito, a ideia de contrato social manter-se-ia no seu prestígio incontestável ${ }^{35}$. Isso por que os princípios do direito seriam racionais, enquanto que a felicidade não.

Apesar de toda a peculiaridade do legislador explicitada por Kant nesses argumentos contra a rebelião, ele ainda afirma que a liberdade de escrever - entendida aqui também como liberdade de imprensa - é o único recurso do povo. Desde que os escritores não percam seu direito à liberdade, ou seja, instiguem uma rebelião ou qualquer coisa do gênero, pensar por si mesmo e tornar público o seu pensamento não constitui apenas um direito para Kant, mas um dever que, como vimos anteriormente, constitui uma das partes essenciais da função prática e moral do filósofo: ir ao mundo (de maneira metafórica) e fazer uso de sua razão, procurando pelos fins últimos da razão humana.

Se uma lei que impeça o progresso da humanidade ou dos fins que ela busca, por exemplo, de artigos de fé, religiões externas etc., torna-se patente que um contrato originário do povo, que fizesse semelhante lei seria em si mesmo nulo e sem validade ${ }^{36}$. Além disso, para Kant, a obediência sem liberdade não constitui validade para qualquer constituição civil. Para exemplificar, podemos relembrar o caso da escravidão. Isso tem de ser assim, porque no tocante ao dever universal dos homens, cada qual exige ser convencido pela razão de que semelhante coação é conforme o direito a fim de não entrar em contradição consigo mesmo ${ }^{37}$. Novamente, vale mencionar que Kant não quer instituir um estado civil que prive a liberdade que o homem no estado de natureza teria. O que ele quer parece ser o estabelecimento de outra qualidade para essa liberdade.

Por fim, Kant alega que é no campo da constituição política que a práxis se pronuncia com maior pretensão que a teoria. O motivo disso seria a ausência do uso da razão no julgamento que o povo faz da legislação vigente de seu Estado. O povo prefere a passividade perante o Estado, situação perigosa na perspectiva kantiana, pois o contentamento e a prática dócil à experiência sobre as diversas constituições defeituosas que existem há tempos, revela o fracasso da teoria em proporcionar a prosperidade do povo. A menoridade é cômoda, o pensamento racional é espinhoso. Porém, é devido a essa menoridade dos homens que, mesmo conscientes dos direitos, são incapazes e, portanto, indignos de serem tratados pelo Estado em conformidade com esses direitos ${ }^{38}$.

Nesse ponto, a única possibilidade de se evitar o extermínio das constituições vigentes e, consequentemente, o retorno ao estado de natureza é um Estado que usa o seu poder para manter a ordem, procedendo ao menos segundo as regras de prudência. Isso, para Kant, é um salto desesperado, evitável se a voz dos direitos que é proveniente da vontade comum e, portanto da razão, falar mais alto que a menoridade que endurece o coração dos homens.

\footnotetext{
${ }^{35}$ KANT, Immanuel. A Paz Perpétua e outros Opúsculos, p.89.

${ }^{36}$ KANT, Immanuel. A Paz Perpétua e outros Opúsculos, p.92.

${ }^{37}$ Cf. KANT, Immanuel. A Paz Perpétua e outros Opúsculos, p.92.

${ }^{38}$ KANT, Immanuel. A Paz Perpétua e outros Opúsculos, p.93-94.
}

\begin{tabular}{|c|c|l|l|l|l|}
\hline intuitio & $\begin{array}{c}\text { ISSN } \\
1983-4012\end{array}$ & Porto Alegre & Vol.7- $\mathrm{N}^{\mathrm{o}} .1$ & $\begin{array}{c}\text { Junho } \\
2014\end{array}$ & p.112-124 \\
\hline
\end{tabular}




\section{Sobre teoria e prática na perspectiva cosmopolita}

Como vimos anteriormente, a felicidade é uma parte da moral que, por sua vez, independe da felicidade. De acordo com Kant, “[...] não é possível, mesmo com o maior esforço por em si se obrigar ao amor, evitar o ódio, não justamente para fazer mal aos homens, mas para lidar o menos possível com eles." 39 A proposta de uma constituição cosmopolita, ou seja, que funda um direito dos homens tem como objetivo criar um único estado em que as disposições da humanidade, as quais tornam a nossa espécie digna de amor, podem desenvolver-se de um modo conveniente.

Dessa forma, é perceptível a importância do papel da razão. É através dela que existe a vontade de fazer algo por um bem geral, em prol da ilustração (esclarecimento) e da prosperidade. Percebe-se ao longo do processo histórico que o gênero humano na sua totalidade progrediu de um modo notável sob o ponto de vista moral, em relação a todas as épocas anteriores.

O que Kant irá se perguntar é: quais os meios para manter esse progresso incessante para melhor? Segundo ele, isso somente é possível através da Providência, ou seja, do desígnio da razão. Isso por que é necessária uma sabedoria superior para a realização desse fim e, é através dela, que podemos esperar um sucesso que concerne tanto ao todo quanto às partes. De acordo com Kant,

[...] esperar da Providência as circunstâncias para tal requeridas; a qual proporcionará ao fim da humanidade no conjunto de sua espécie, para a obtenção do seu destino verdadeiro, mediante o livre uso das suas forças, segundo seu alcance, um desenlace, a que se opõem justamente os fins dos homens individualmente considerados. Pois é precisamente o conflito das tendências entre si, de que promana o mal, que fornece à razão um livre jogo para a todas subjugar; e, em vez do mal, que se destrói a si mesmo, fazer reinar o bem que, uma vez existente, se mantém por si mesmo daí em diante. ${ }^{40}$

No entanto, ingressar nessa constituição cosmopolita, nesse estado de paz universal, não pode ocorrer sob a forma de uma comunidade governada por um chefe, mas sim em um estado jurídico de federação, de acordo com um direito consentido pelas pessoas.

E deste modo, também a posteridade poderá sempre progredir para o melhor, mesmo no sentido moral, sem que a causa disso seja o amor por ela, mas apenas o amor de cada época por si própria: pois toda a comunidade, incapaz de prejudicar outra pela violência, se deve agarrar apenas ao direito e pode com fundamento esperar que outros, assim igualmente configurados, virão em seu auxílio. ${ }^{41}$

Ao introduzir um Estado universal dos povos e supor que sua existência seja possível, deve-se atentar para que a sua constituição seja estabelecida, primariamente, pelo princípio do direito, que nada mais é do que a relação entre os homens e os Estados, na qual existe o respeito pelo direito e pelo dever. Dever esse que é inato, ou seja, enquanto eu, homem em geral, me encontro com a constituição

${ }^{39}$ KANT, Immanuel. A Paz Perpétua e outros Opúsculos, p.95.
${ }^{40}$ KANT, Immanuel. A Paz Perpétua e outros Opúsculos, p.100.
${ }^{41}$ KANT, Immanuel. A Paz Perpétua e outros Opúsculos, p.100.

\begin{tabular}{|l|c|c|c|c|c|}
\hline intuitio & $\begin{array}{c}\text { ISSN } \\
1983-4012\end{array}$ & Porto Alegre & Vol.7- No.1 & $\begin{array}{c}\text { Junho } \\
2014\end{array}$ & p.112-124 \\
\hline
\end{tabular}


moral. Para Kant, ao considerar o ponto de vista cosmopolita "[...] se persiste também na afirmação: o que por razões racionais vale para a teoria, vale igualmente para a prática." 42

\section{Conclusão}

No início desse artigo, foram propostas duas questões: $O$ trabalho acadêmico de pesquisa em filosofia pode se associar com a prática do filósofo? Se há essa possibilidade, como o filósofo deve fazê-lo?

Para responder essas questões faz-se devemos apresentar alguns elementos que permitem expressar uma transformação no modo de pensar e de fundamentar a filosofia moral em Kant, ou seja, os elementos que lhe deram o mérito de promover uma "revolução copernicana" na ética.

Para que essa revolução kantiana da moral aconteça em sua totalidade é necessário, como vimos, que o homem pense por conta própria e, dessa forma, torne-se um legislador da razão. Pensar por si mesmo significa buscar dentro da própria razão o critério supremo da verdade e a máxima de pensar sempre de maneira autônoma é o que melhor define o esclarecimento. Este não consiste em apenas acumular conhecimentos (filosofia na escola), embora esses sejam necessários, mas em fazer uso da própria razão. Para Kant, devemos ter coragem para sair da menoridade, [...] pois ainda não vivemos uma época esclarecida. Vivemos, antes, em época de esclarecimento. É preciso tomar consciência de que somos seres humanos e enquanto tal, temos dignidade e somos capazes de razão. ${ }^{43}$

À luz do lema do esclarecimento, Kant quer encorajar todo ser humano a fazer uso de sua própria razão tanto em seu uso teórico como prático. O primeiro não deve obstruir o segundo, mas sim deixar-lhe um lugar de acesso.

Para validar uma filosofia da moral universal, Kant elaborará uma filosofia moral pura, independente de tudo que possa ser empírico, isto é, de uma teoria válida moralmente não apenas para o ser humano, mas para todos os seres racionais em geral. É no domínio da moral que o homem pode se afirmar verdadeiramente como livre, incondicionado e legislador de si próprio. É também neste domínio que, pela liberdade, estabelece-se a relação entre a felicidade e a moralidade. Para Kant, essa relação estabelece o fim último do homem, a meta final da razão, que consiste na união e no acordo entre a moralidade e a felicidade.

Segundo Kant, essa relação entre moral e felicidade pode ser posta pelo princípio do dever que

[...] não precisa, para se fundar, de nenhum fim particular, mas que, pelo contrário, suscita um outro fim para a vontade do homem, a saber: contribuir por todos os meios para o soberano bem possível no mundo (a felicidade geral no universo, associada à mais pura moralidade e conforme com ela. ${ }^{44}$

\footnotetext{
${ }^{42}$ KANT, Immanuel. A Paz Perpétua e outros Opúsculos, p.102.

${ }^{43}$ NODARI, Paulo César. A teoria dos dois mundos e o conceito de liberdade em Kant, p.158.

${ }^{44}$ KANT, 1996, p.62.
}

\begin{tabular}{|l|c|l|l|l|l|}
\hline intuitio & $\begin{array}{c}\text { ISSN } \\
1983-4012\end{array}$ & Porto Alegre & Vol.7- $\mathrm{N}^{\circ} .1$ & $\begin{array}{c}\text { Junho } \\
2014\end{array}$ & p.112-124 \\
\hline
\end{tabular}


A noção de dever kantiana é derivada da noção de boa vontade. Para Kant, a boa vontade é primordial, pois é a única boa em si (livre de inclinações) por possuir valor absoluto e constituir a condição indispensável do próprio fato do ser humano ser digno de felicidade. Assim, "a boa vontade não é boa pelo que promove, realiza ou então pela aptidão para alcançar qualquer finalidade proposta, mas tão somente pelo querer, isto é, em si mesma, já que a boa vontade tem nela mesma seu pleno valor". 45

O que torna boa a vontade é a própria vontade e natureza do querer. A boa vontade é a vontade de agir por dever. Ela é seguramente agir por dever e revela-se na luta contra as disposições naturais. Devemos fazer o que o dever te ordena. Ser livre, por conseguinte, significa simplesmente ter uma vontade que se deixa comandar pela razão.

Pode-se afirmar que Kant percebe uma nova concepção da razão prática pura. Ela passa a ser entendida como um meio para produzir a boa vontade. Contudo, para que isso seja possível, três aspectos devem ser salientados na elaboração dos fundamentos da filosofia moral: "o princípio da generalidade como universalidade (autonomia da moral), a necessidade de que o conceito do dever não seja, de modo algum, empírico e que os conceitos da ética não sejam, absolutamente, ganhos da experiência." ${ }^{46}$

A tese da revolução copernicana de Kant na ética consiste na descoberta da autonomia da vontade como o princípio supremo da moralidade. Para que a vontade seja autônoma, a força da autonomia não deve provir de uma fonte externa e estranha ao próprio sujeito, mas tão somente da própria razão. Por isso, a autonomia da vontade não significa senão a capacidade de o ser humano dar a si mesmo a lei moral com valor universal. Assim, se a lei moral tem valor por si mesma, então ela se constitui como uma lei da vontade racional e universal.

Chegamos enfim ao ponto de poder esclarecer o porquê e o modo de proceder que Kant atribui ao filósofo enquanto cidadão, ou seja, enquanto membro de um estado civil, pautado por uma constituição civil vigente. Apesar de mostrar essa perspectiva, o ponto de chegada da formação filosófica não se encerra no reconhecimento de um mero cidadão, mas de um cidadão cosmopolita; um cidadão do mundo, que considera em seus princípios abstraídos de regras gerais a vontade comum de todos os homens.

Como vimos, apesar da formação na escola ser o ponto de partida da formação filosófica, feita por reconhecimento da história da filosofia e do uso da razão para resolução de problemas teóricos, ela não exauri a função do filósofo. Mais que isso, é no mundo, na prática, que o filósofo deve encontrar o seu caminho, saindo da menoridade e da apatia política para tornar pública a vontade comum dos homens em serem livres.

É função de todo cidadão esclarecido tornar o uso da razão um meio para se chegar ao progresso da humanidade, ou dos fins que essa humanidade almeja. Em um caso mais específico, essa

\footnotetext{
${ }^{45}$ KANT, 1986, p.23.

${ }^{46}$ NODARI, Paulo César. A teoria dos dois mundos e o conceito de liberdade em Kant, p.160.
}

\begin{tabular}{c|c|c|c|}
$\begin{array}{c}\text { ISSN } \\
1983-4012\end{array}$ & Porto Alegre & Vol.7- No.1 & $\begin{array}{c}\text { Junho } \\
2014\end{array}$ \\
\hline
\end{tabular}


razão deve tornar mais claro e acessível a todos que os direitos são princípios supremos das leis, não permitindo que um Estado déspota desabilite o direito de liberdade de escolha, por um conceito de felicidade que lhe convém. Esse dever, não é função apenas de todo cidadão, mas dos legisladores justos também.

Portanto, escola/teoria e mundo/prática mostram-se na filosofia kantiana como o único modo conciliável entre uma constituição civil adequada, pautada principalmente pelo princípio da liberdade, e leis justas derivadas da vontade do povo.

\section{Referências}

FERRAZ, C. A. "Quando Ética e Política se encontram: Kant, o projeto de 'À Paz Perpétua' e as bases para um 'Direito dos Povos"'. In: Dissertatio: Revista de Filosofia. v. 34, pp. 209-229, 2011. Disponível em: $\langle$ http://www.ufpel.edu.br/isp/dissertatio/revistas/34/09.pdf >. Acesso em: 10/02/2013.

KANT, Immanuel. A Paz Perpétua e outros Opúsculos. Tradução de Artur Morão. Lisboa: Edições 70, 1995.

Manual dos cursos de lógica geral. Tradução e apresentação de Fausto Castilho. Edição bilíngüe. Campinas: IFCH-UNICAMP; Uberlândia: EDUFU, 1998.

¿Qué es la Ilustración? Y otros escritos de ética, política y filosofia de La historia. Edição de Roberto R. Aramayo. Madrid: Alianza, 2004.

. Resposta a pergunta: Que é esclarecimento? Textos Seletos. Tradução Floriano de Sousa Fernandes.

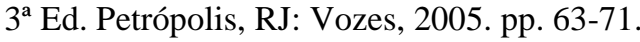

NODARI, Paulo César. A teoria dos dois mundos e o conceito de liberdade em Kant. Caxias do Sul: Educs, 2009.

Novo Código Civil. Lei ${ }^{\circ} 10.403$ de 10 de janeiro de 2002. Brasília, DF, 2002. Disponível em: <http://www.planalto.gov.br/ccivil 03/leis/2002/L10406.htm>. Acesso em: 17/02/2013.

SENEDA, Marcos César. "Conceitos de filosofia na escola e no mundo e a formação do filósofo segundo I. Kant". Kriterion: Revista de Filosofia, Belo Horizonte, v. 50, n. 119, junho, 2009.

WOLFF, Christian. Discours préliminaire sur la philosophie en general. Paris: Vrin, 2006.

Recebido em: 24/09/2013

Aprovado para publicação em: 06/04/2014

\begin{tabular}{|l|c|l|l|l|l|}
\hline intuitio & $\begin{array}{c}\text { ISSN } \\
1983-4012\end{array}$ & Porto Alegre & Vol.7- $\mathrm{N}^{\mathrm{o} .1}$ & $\begin{array}{c}\text { Junho } \\
2014\end{array}$ & p.112-124 \\
\hline
\end{tabular}

